Article

\title{
Pd nanoparticles confined in fluoro-functionalized yolk-shell-structured silica for olefin hydrogenation in water
}

\author{
LI Xiaofei a,b, ZHANG Wenjuan b , ZHANG Limin a,*, YANG Hengquan b,\# \\ a School of Chemistry and Materials Science, Shanxi Normal University, Linfen 041000, Shanxi, China \\ b School of Chemistry and Chemical Engineering, Shanxi University, Taiyuan 030006, Shanxi, China
}

A R T I C L E I N F 0

Article history:

Received 24 December 2012

Accepted 5 March 2013

Published 20 June 2013

\section{Keywords:}

Palladium

Functionalization

Olefin

Aqueous phase

Hydrogenation

\section{A B S T R A C T}

Pd nanoparticles were confined in yolk-shell mesoporous silica via encapsulation, etching and modification, producing a functionalized yolk-shell-structured catalyst. This catalyst was characterized using X-ray diffraction analysis, transmission electron microscopy, $\mathrm{N}_{2}$ adsorption-desorption, and thermogravimetric analysis. The catalyst had high activity for olefin hydrogenation in water, higher than that of the unmodified counterpart. The catalyst can be recovered through centrifugation, and its activity is not significantly decreased after several reaction cycles.

(C) 2013, Dalian Institute of Chemical Physics, Chinese Academy of Sciences. Published by Elsevier B.V. All rights reserved.

\section{Introduction}

Recently, using water as a medium in catalytic reactions has attracted extensive attentions because of it is low-cost, safe, and pollution-free [1-6]. However, because of its low solubility in water, most organic reactants cannot completely contact with the catalyst, which leads to low conversion in catalytic reactions. The addition of co-solvent or surfactants can improve the reaction rate $[7,8]$, but introduction of auxiliary additives violates the green chemistry principles. It is also difficult to separate and purify the products. Therefore, development of a highly active catalyst for water-mediated systems is still a challenge.

Yolk-shell microspheres have emerged as a rapidly growing catalysis research theme because of their unique structure [9-20], compared with conventional structures, such as MCM-41 and SBA-15. First, yolk-shell microspheres have a special hollow structure and low density, which are conductive to the catalyst suspension in water. The reactants also diffuse quickly to the surface of the catalyst because of the hollow structure, which can further improve the reaction rate [21,22]. Second, yolk-shell microspheres have interstitial space between the shell and the core, which can enrich more reactants and provide greater possibility for effective reactants to interact with the catalyst. Third, the outer shell can hinder the aggregation of neighboring particles, which enhances their stability [23].

Catalytic performance can be improved by increasing the hydrophobicity of the catalysts. Yang and co-workers [24] found that organically functionalized mesoporous materials exhibit significantly enhanced hydrothermal and mechanical stability. Hydrophobic mesoporous materials can also increase the adsorption of hydrophobic pollutants in aqueous solutions $[25,26]$. Therefore, catalyst hydrophobization can exhibit sig-

\footnotetext{
*Corresponding author. Tel: +86-13663578554; E-mail: zhangliminsxnu@gmail.com

\# Corresponding author. Tel: +86-13643472170; E-mail: hqyang@sxu.edu.cn

This work was supported by the National Natural Science Foundation of China (20903065 and 21173137).

DOI: 10.1016/S1872-2067(12)60561-0 | http://www.sciencedirect.com/science/journal/18722067 | Chin. J. Catal., Vol. 34, No. 6, June 2013
} 
nificantly enhanced activity in aqueous environments [27,28]. However, much higher hydrophobicity of the catalyst can hinder effective interactions with the reactants, which leads to low catalyst activity.

The fluoropropyl group is a moderately hydrophobic functional group. Fluoro-functionalized solid catalysts are hydrophobic, causing increased adsorption of the reactants $[29,30]$, and leading to an enhanced reaction rate. Until recently, little attention had been paid to the preparation of the fluoropropyl-functionalized yolk-shell structured catalysts and their catalytic performance in water systems.

In this work, we report the synthesis of fluoro-functionalized yolk-shell silica with Pd nanoparticles cores (yPd@mSiO $2-F)$ via impregnation-reduction, encapsulation, etching and grafting. The structure and composition of the samples were characterized with X-ray diffraction (XRD), transmission electron microscope (TEM), $\mathrm{N}_{2}$ adsorption-desorption, and thermal gravimetric analysis (TGA). The catalytic reactivity and recycling performance were studied through hydrogenation in water.

\section{Experimental}

\subsection{Preparation of catalyst}

Deionized water $(20 \mathrm{ml})$ and ammonia solution $(12.2 \mathrm{ml}$, $25 \%$ ) were added to $200 \mathrm{ml}$ of absolute ethanol. After vigorous stirring for $30 \mathrm{~min}, 12.4 \mathrm{ml}$ of tetraethylorthosilicate (TEOS) was slowly added. After further stirring for $12 \mathrm{~h}$, aqueous-phase dispersed silica nanospheres were generated. The silica nanospheres $\left(\mathrm{SiO}_{2}\right)$ [31] were obtained by filtration, purification with deionized water and drying at room temperature.

The prepared $\mathrm{SiO}_{2}(0.8 \mathrm{~g})$ was added to $10 \mathrm{ml}$ of toluene containing $0.0084 \mathrm{~g}$ of $\mathrm{Pd}(\mathrm{OAc})_{2}$. After stirring for $4 \mathrm{~h}$ at room temperature, the toluene was removed by centrifugation to obtain the Pd-adsorbed solid. The solid was then reduced with $\mathrm{NaBH}_{4}$ in $16 \mathrm{ml}$ of toluene and ethanol $(V / V=20: 1)$. This solid was separated by centrifugation and washed with ethanol. After vacuum drying, $\mathrm{Pd} / \mathrm{SiO}_{2}$ was obtained.

The prepared $\mathrm{Pd} / \mathrm{SiO}_{2}(0.6 \mathrm{~g})$ was dispersed into $120 \mathrm{ml}$ of $\mathrm{H}_{2} \mathrm{O}$ using ultrasound. Cetyltrimethylammonium bromide (CTAB ) solution containing $0.9 \mathrm{~g} \mathrm{CTAB}, 180 \mathrm{ml}$ water, $180 \mathrm{ml}$ ethanol, and $3.3 \mathrm{ml}$ ammonia solution (25\%) were slowly added under stirring. TEOS (1.0575 g) was successively added to the solution under stirring. After centrifugation, the materials were added to $120 \mathrm{ml}$ of deionized water and uniformly dispersed under ultrasonic. Sodium carbonate $(2.544 \mathrm{~g})$ was added for etching at $50{ }^{\circ} \mathrm{C}$ for $12 \mathrm{~h}$ under $\mathrm{N}_{2}$ atmosphere. The final product was denoted as yPd@ $\mathrm{mSiO}_{2}$.

To synthesize the yolk-shell yPd@ $\mathrm{mSiO}_{2}-\mathrm{F}, 0.5 \mathrm{~g}$ of $\mathrm{yPd} @ \mathrm{mSiO}_{2}$ and $0.1635 \mathrm{~g}$ of 3,3,3-trifluoropropyltrimethoxysilane were added to $5 \mathrm{ml}$ of toluene solution and refluxed for $4 \mathrm{~h}$ under a $\mathrm{N}_{2}$ atmosphere at $100{ }^{\circ} \mathrm{C}$. The final material denoted as yPd@mSiO $2-F$ was prepared by centrifugation and washed with toluene and ethanol.
TEM was performed using a JEM-2000EX (JEOL, Japan, Akishima) at an acceleration voltage of $120 \mathrm{kV}$. Nitrogen sorption isotherms were measured at $-196{ }^{\circ} \mathrm{C}$ with an ASAP2020 volumetric adsorption analyzer. The BET surface area was calculated from the adsorption data in the relative pressure range $p / p_{0}$ from 0.05 to 0.3 . Pore size distribution was determined from the desorption branch of the isotherm using the $\mathrm{BJH}$ method. Pore volume was estimated at a relative pressure $p / p_{0}$ of 0.995. XRD patterns were recorded on a Rigaku D/max-2400 $\mathrm{X}$-ray diffractometer (at $40 \mathrm{kV}$ and $100 \mathrm{~mA}$ of $\mathrm{Cu} K_{a}$ radiation). TGA was performed with a NETZSCH TG analyzer (Germany) under nitrogen from room temperature to $900{ }^{\circ} \mathrm{C}$ with a heating rate of $25^{\circ} \mathrm{C} / \mathrm{min}$.

\subsection{Hydrogenation of olefin}

For hydrogenation of olefin, the catalytic experiment was carried out in a three-necked flask fitted with water bath, thermocouple, and magnetic stirrer. A mixture of $\mathrm{H}_{2} \mathrm{O}(6 \mathrm{ml})$, substrate $(1 \mathrm{mmol})$, and catalyst $(0.1 \mathrm{~mol} \%)$ was prepared in the three-necked flask. After air was flushed out of the reactor, bath was heated to reaction temperature and then was pressurized with $\mathrm{H}_{2}$ to $0.15 \mathrm{MPa}$. Then the mixture was stirred at $500 \mathrm{r} / \mathrm{min}$ and the reaction was considered to start. After the reaction, the catalyst was removed from the reaction mixture by centrifugation; the products were analyzed by gas chromatography (Agilent 7890A) with a flame ionization detector.

\section{Results and discussion}

\subsection{Catalyst preparation and characterization}

The typical procedure for the preparation of yolk-shell yPd@ $\mathrm{mSiO}_{2}$ is outlined in Fig. 1. To confine the Pd nanoparticles to the interior of the yolk-shell, we loaded the Pd nanoparticles on $\mathrm{SiO}_{2}$ spheres through dipping and reduction, and grew a silica shell on its surface in the presence of CTAB, then etched the $\mathrm{SiO}_{2}$ core with $\mathrm{Na}_{2} \mathrm{CO}_{3}$. A yolk-shell-structure catalyst was obtained after removing the template by solvent extraction. A previous method mentioned in the literature obtains a hollow structure using high temperature calcination to remove the carbon sphere [32]. Our preparation is implemented under milder conditions, which avoids the collapse of structure and deactivation of the active component that may be caused by

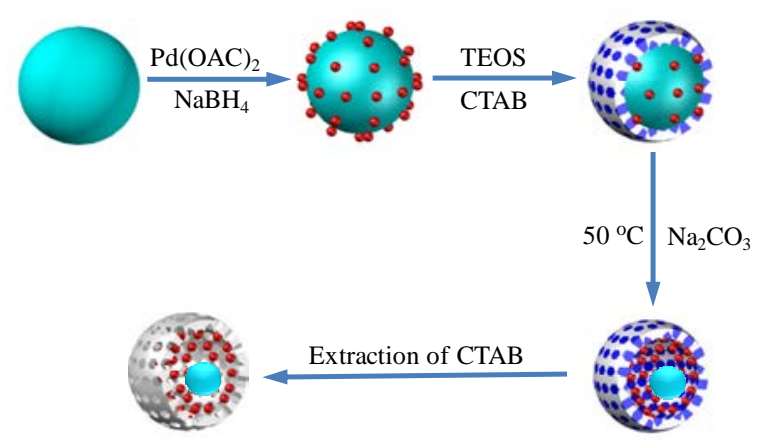

Fig. 1. Illustration of the synthesis procedure for the yolk-shell

$\mathrm{yPd} @ \mathrm{mSiO}_{2}$.

\subsection{Characterization}




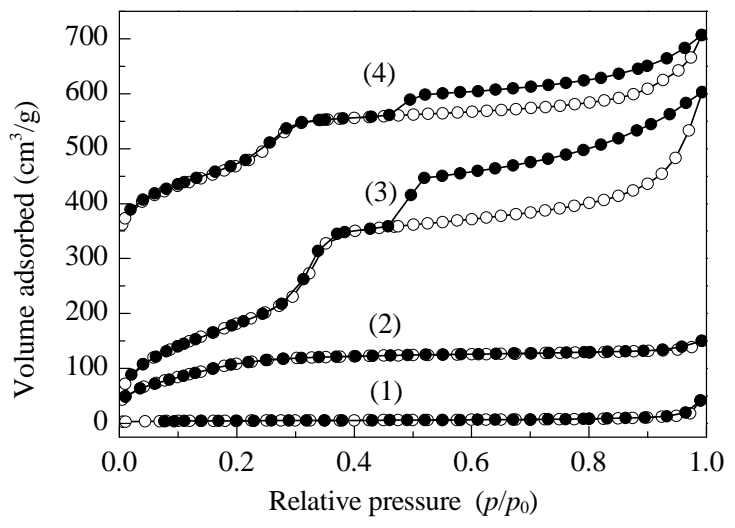

Fig. 2. $\mathrm{N}_{2}$ adsorption-desorption isotherms of $\mathrm{SiO}_{2}(1), \mathrm{Pd} / \mathrm{SiO}_{2} @ \mathrm{mSiO}_{2}$

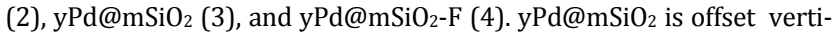
cally by 300; yPd@ $\mathrm{mSiO}_{2}-\mathrm{F}$ is offset vertically by 50 .

calcination under high temperature.

The structures of the synthesized materials were characterized by $\mathrm{N}_{2}$ sorption. $\mathrm{N}_{2}$ sorption isotherms are displayed in Fig. 2 , and the parameters are summarized in Table 1 . The $\mathrm{N}_{2}$ adsorption amount of $\mathrm{SiO}_{2}$ was very small in the entire pressure ranges, with a surface area of only $18 \mathrm{~m}^{2} / \mathrm{g}$ and pore volume of $0.06 \mathrm{~cm}^{3} / \mathrm{g}$. Pd $/ \mathrm{SiO}_{2} @ \mathrm{mSiO}_{2}$ was achieved after encapsulating $\mathrm{Pd} / \mathrm{SiO}_{2}$ with $\mathrm{SiO}_{2}$, showing a type IV sorption isotherm. The capillary condensation steps were shown in the relative pressure range of $0.1-0.3$. The data show that specific surface area increased to $408 \mathrm{~m}^{2} / \mathrm{g}$ and the pore volume increased to 0.23 $\mathrm{cm}^{3} / \mathrm{g}$, which is due to the formation of the porous structure on the $\mathrm{Pd} / \mathrm{SiO}_{2}$ surface. The adsorption isotherm of $\mathrm{yPd} @ \mathrm{mSiO}_{2}$ was also close to type IV. The capillary condensation steps were shown in the relative pressure range of $0.3-0.5$, indicating that a mesoporous structure had formed. In addition, there was no overlap between the yPd@ $\mathrm{mSiO}_{2}$ adsorption branch and the desorption branch in the relative pressure range of 0.5-1.0. A clear $\mathrm{H} 4$ type hysteresis loop proved that the material had a hollow structure. In comparison to $\mathrm{Pd} / \mathrm{SiO}_{2} @ \mathrm{mSiO}$, the specific surface area and pore volume of yPd@ $\mathrm{mSiO}_{2}$ increased, respectively, to $841 \mathrm{~m}^{2} / \mathrm{g}$ and $1.01 \mathrm{~cm}^{3} / \mathrm{g}$. This was mainly because the $\mathrm{SiO}_{2}$ cores were etched away, and the template had been fully removed. There was no significant difference between the yPd@ $\mathrm{mSiO}_{2}$ adsorption branch and the $\mathrm{yPd} @ \mathrm{mSiO}_{2}$ desorption branch, but the specific surface area, pore volume
Table 1

Texture properties of the samples.

\begin{tabular}{lccc}
\hline Sample & $A_{\text {BET }} /\left(\mathrm{m}^{2} / \mathrm{g}\right)$ & $V^{\mathrm{a}} /\left(\mathrm{cm}^{3} / \mathrm{g}\right)$ & Pore size $^{\mathrm{b}}(\mathrm{nm})$ \\
\hline $\mathrm{SiO}_{2}$ & 18 & 0.06 & - \\
$\mathrm{Pd} / \mathrm{SiO}_{2} @ \mathrm{mSiO}_{2}$ & 408 & 0.23 & 1.90 \\
$\mathrm{yPd} @ \mathrm{mSiO}_{2}$ & 841 & 1.01 & 2.85 \\
$\mathrm{yPd} @ \mathrm{mSiO}_{2}-\mathrm{F}$ & 619 & 0.63 & 2.40 \\
\hline
\end{tabular}

a Single point pore volume calculated at relative pressure $p / p_{0}$ of 0.99 .

${ }^{\mathrm{b}} \mathrm{BJH}$ method from adsorption branch.

and pore size were significantly reduced, indicating that the fluoropropyl groups were successfully grafted onto yPd@mSiO 2 .

Typical TEM images of $\mathrm{SiO}_{2}$ and yPd@mSiO 2 are shown in Fig. 3. The obtained $\mathrm{SiO}_{2}$, with an average particle size of 200 $\mathrm{nm}$, is shown in Fig. 3(a). For the $\mathrm{Pd} / \mathrm{SiO}_{2}$ sample, Pd nanoparticles sizes are uniformly distributed over a range of 4-10 $\mathrm{nm}$. After encapsulation, etching and modification, uniform and nearly monodisperse yolk-shell yPd@mSiO 2 (Fig. 3(c)) with an average particle size of $500 \mathrm{~nm}$ were obtained. The size of the microspheres was significantly greater than $\mathrm{SiO}_{2}$.

The XRD patterns of $\mathrm{yPd} @ \mathrm{mSiO}_{2}$ and $\mathrm{yPd} @ \mathrm{mSiO}_{2}-\mathrm{F}$ are shown in Fig. 4. The XRD patterns of yPd@ $\mathrm{mSiO}_{2}$ are similar to $\mathrm{yPd} @ \mathrm{mSiO}_{2}-\mathrm{F}$, showing one diffraction peak at $2 \theta \approx 2.3^{\circ}$ of similar intensity. The XRD and TEM results suggest that the yolk-shell-structured silica still possesses a mesoporous shell.

The TG plots for yPd@mSiO 2 and yPd@ $\mathrm{mSiO}_{2}-\mathrm{F}$ are shown in Fig. 5. TG curves reveal that three stages of decomposition

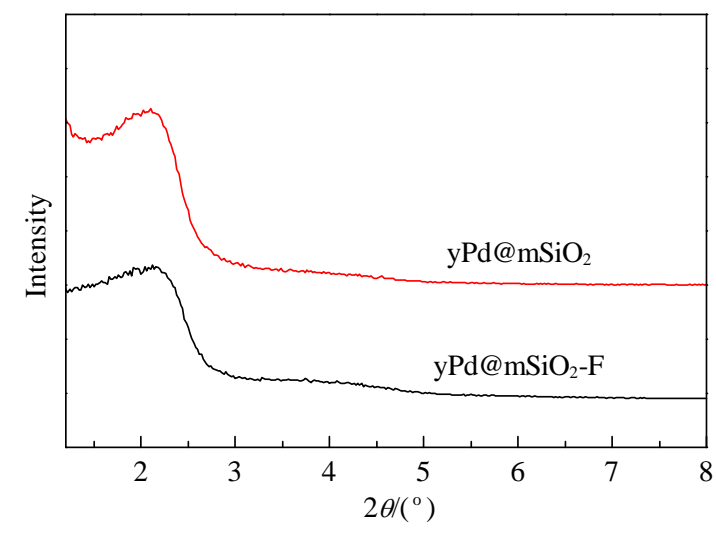

Fig. 4. XRD patterns of $y \mathrm{Pd} @ \mathrm{mSiO}_{2}$ and $\mathrm{yPd} @ \mathrm{mSiO}_{2}-\mathrm{F}$ samples.
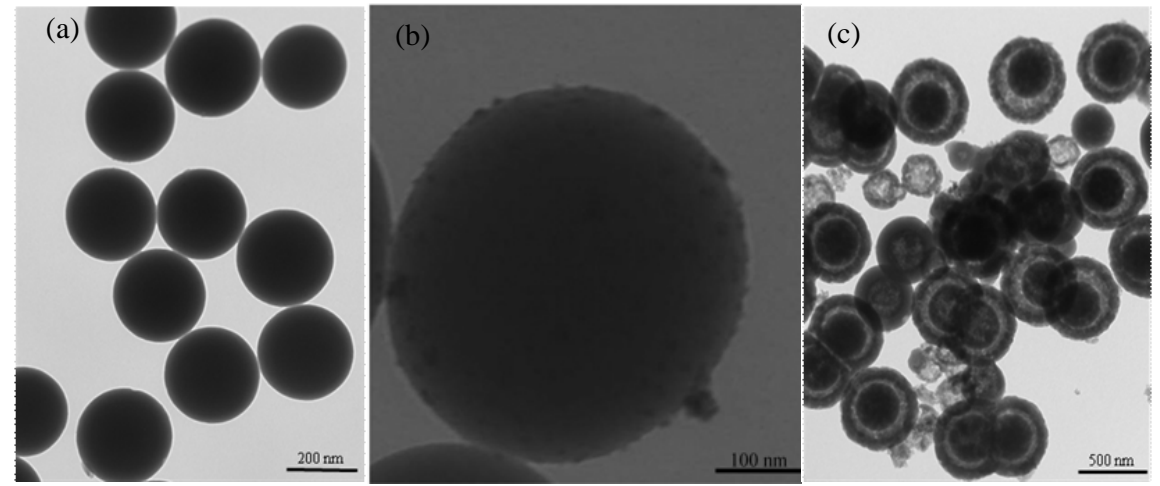

Fig. 3. TEM images of $\mathrm{SiO}_{2}(\mathrm{a}), \mathrm{Pd} / \mathrm{SiO}_{2}$ (b), and $\mathrm{yPd} @ \mathrm{mSiO}_{2}$ (c). 


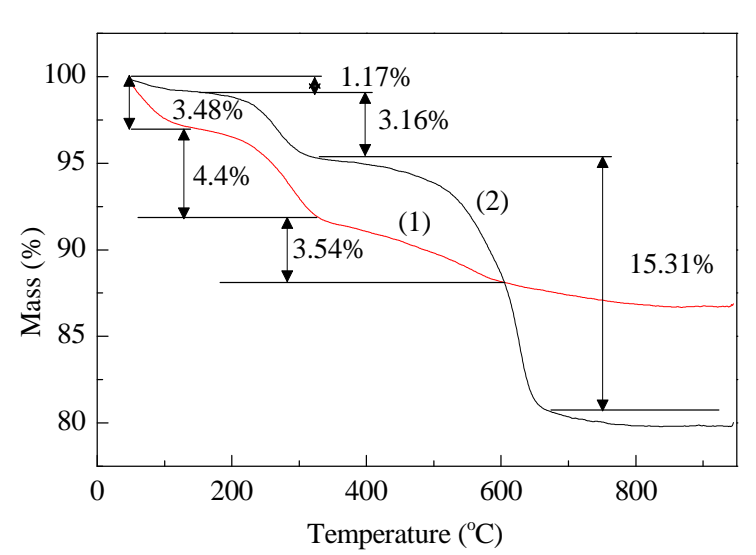

Fig. 5. TGA curves of yPd@mSiO 2 (1) and yPd@mSiO $2-F(2)$ samples.

occur for yPd@mSiO 2 . Similar results have been found for $\mathrm{yPd} @ \mathrm{mSiO}_{2}-\mathrm{F}$. Stage 1 is from the start temperature $\left(50{ }^{\circ} \mathrm{C}\right)$ to $200{ }^{\circ} \mathrm{C}$, stage 2 is from 200 to $320^{\circ} \mathrm{C}$, and the third stage is from 320 to $900{ }^{\circ} \mathrm{C}$. In stage $1, \mathrm{yPd} @ \mathrm{mSiO}_{2}$ experiences about $3.48 \%$ weight loss mainly due to the elimination of the physically adsorbed water, but yPd@mSiO2-F only undergoes 1.17\% of weight loss. This is mainly due to the introduction of fluoropropyl, causing an increace in the hydrophobicity of the surface of the material and reducing the adsorption quantity of water. In stage 2 , there is a $4.4 \%$ weight loss for $\mathrm{yPd} @ \mathrm{mSiO}_{2}$, and $3.16 \%$ for $\mathrm{yPd} @ \mathrm{mSiO}_{2}-\mathrm{F}$, where most of the template is released. Most of the weight loss that takes place in stage 3 is due to the elimination of condensation dehydration of the silica groups. In this stage, there can be up to $15.31 \%$ weight loss for yPd@mSiO2-F, and higher than 3.54\% for yPd@mSiO2. This is mainly due to the decomposition of grafted fluoropropyl group and the condensation dehydration of silica groups at high temperatures. According to the TG results, we can calculate the loading of fluoropropyl to be about $1.2 \mathrm{mmol} / \mathrm{g}$, which is consistent with the results of elemental analysis.

\subsection{Catalytic activity of the catalysts}

Many studies [33-35] have been conducted concerning the hydrogenation of olefin in aqueous media because of its importance in industrial fields. This paper looks at hydrogenation in water to evaluate the catalytic activity of yolk-shell structure materials. yPd@ $\mathrm{mSiO}_{2}-\mathrm{F}$ and $\mathrm{yPd} @ \mathrm{mSiO}_{2}$ were used in the hydrogenation of methyl acrylate, and the reaction rate monitored by recording the $\mathrm{H}_{2}$ pressure with the results shown in Fig. 6. Under the same conditions, the consumption of hydrogen on the $\mathrm{yPd} @ \mathrm{mSiO}_{2}-\mathrm{F}$ is significantly faster than on the $\mathrm{yPd} @ \mathrm{mSiO}_{2}$. This demonstrates that the activity of $\mathrm{yPd} @ \mathrm{mSiO}_{2}-\mathrm{F}$ is much higher than yPd@ $\mathrm{mSiO}_{2}$. For the ethyl methacrylate, similar results were obtained, as shown in Fig. 7. The hydrogen consumption rate of the above two substrates proves that yPd@mSiO $2-\mathrm{F}$ has a higher catalytic activity.

Hydrogenation of several typical olefins under aqueous conditions was further explored. Hydrogenation of all the olefins proceeded efficiently and quantitative yields were almost achieved (Table 2). Of all the olefins, styrene, with the smallest

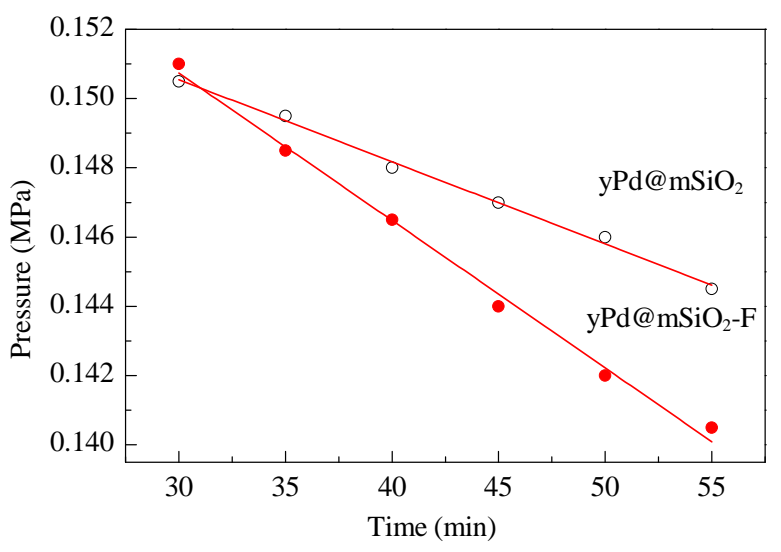

Fig. 6. The reaction kinetics of hydrogenation of methyl acrylate over the two catalysts in pure water. Reaction conditions: substrate $2 \mathrm{mmol}$, water $6 \mathrm{ml}, 0.15 \mathrm{MPa}, 0.1 \% \mathrm{Pd}, 30^{\circ} \mathrm{C}$, fixed stirring rate.

polarity smallest afforded conversions of $45 \%$ with yPd@ $\mathrm{mSiO}_{2}$ and $88 \%$ with yPd@mSiO $2-F$ within $45 \mathrm{~min}$. For aliphatic olefins, butyl acrylate, butyl methacrylate, methyl acrylate, and ethyl methacrylate, the conversion rate on $\mathrm{yPd} @ \mathrm{mSiO}_{2}-\mathrm{F}$ was much higher than on $\mathrm{yPd} @ \mathrm{mSiO}_{2}$ under the same conditions. For acrylamide, yPd@mSiO 2 offered a $49 \%$ conversion within $60 \mathrm{~min}$, and yPd@mSiO $2-\mathrm{F}$ offered 99\%, where the latter is much higher than the former. The results further confirm that $\mathrm{yPd} @ \mathrm{mSiO}_{2}-\mathrm{F}$ shows higher activity than $\mathrm{yPd} @ \mathrm{mSiO}_{2}$ for the hydrogenations of olefins. This is because the shell of yPd@mSiO 2 was modified by fluoropropyl, and exhibited moderate hydrophobicity. This drives the organic reactants into the intracavity of the yolk-shell, promoting sufficient contact of the reactant and the Pd nanoparticles, leading to an improved reaction rate.

\subsection{Catalyst recycling}

The reusability of catalysts is very important theme and makes them useful for commercial applications. Thus, the recovery and reusability of $\mathrm{yPd} @ \mathrm{mSiO}_{2}-\mathrm{F}$ has been investigated using butyl acrylate as a model substrate. The results are tabu-

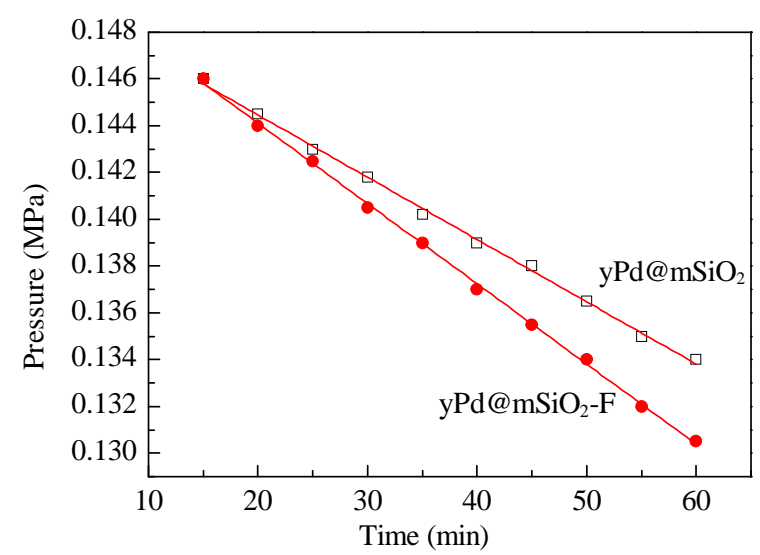

Fig. 7. The reaction kinetics of hydrogenation of ethyl methacrylate over the two catalysts in pure water. Reaction conditions: substrate 2 mmol, water $6 \mathrm{ml}, 0.15 \mathrm{MPa}, 0.1 \% \mathrm{Pd}, 25^{\circ} \mathrm{C}$, fixed stirring rate. 
Table 2

Results of hydrogenation of different substrates over the two catalysts.

\begin{tabular}{|c|c|c|c|c|c|c|c|}
\hline \multirow{2}{*}{ Entry } & \multirow{2}{*}{ Substrate } & \multirow{2}{*}{ Product } & \multirow{2}{*}{$\begin{array}{l}\text { Time } \\
\text { (min) }\end{array}$} & \multirow{2}{*}{$\begin{array}{c}\text { Temperature } \\
\left({ }^{\circ} \mathrm{C}\right)\end{array}$} & \multirow{2}{*}{$\begin{array}{c}\text { Pressure } \\
\text { (MPa) }\end{array}$} & \multicolumn{2}{|c|}{ Conversion a (\%) } \\
\hline & & & & & & $\mathrm{yPd} @ \mathrm{mSiO}_{2}$ & $\mathrm{yPd} @ \mathrm{mSiO}_{2}-\mathrm{F}$ \\
\hline 1 & & & 45 & 25 & 0.15 & 45 & 88 \\
\hline 2 & & & 30 & 30 & 0.15 & 48 & 96 \\
\hline 3 & & & 60 & 50 & 0.30 & 79 & 92 \\
\hline 4 & & & 60 & 35 & 0.15 & 49 & 99 \\
\hline 5 & & & 45 & 30 & 0.15 & 65 & 94 \\
\hline 6 & & & 60 & 25 & 0.15 & 71 & 94 \\
\hline
\end{tabular}

Reaction conditions: substrate $1 \mathrm{mmol}, 0.1 \mathrm{~mol} \% \mathrm{Pd}, \mathrm{H}_{2} \mathrm{O} 6 \mathrm{ml}$. a Determined by GC

Table 3

Recycling results of yPd@mSiO $2-F$.

\begin{tabular}{|c|c|}
\hline Cycle & Conversion $^{*}(\%)$ \\
\hline 1 & 99 \\
\hline 2 & 99 \\
\hline 3 & 98 \\
\hline 4 & 99 \\
\hline 5 & 99 \\
\hline
\end{tabular}

Reaction conditions: substrate $1 \mathrm{mmol}, 0.2 \%$ Pd, water $3 \mathrm{ml}, 40{ }^{\circ} \mathrm{C}, 1.5$ h, ambient $\mathrm{H}_{2}$ pressure. ${ }^{*}$ Determined by GC.

lated in Table 3 . The catalyst is highly reusable, retaining its catalytic activity over five reaction cycles. The conversion rate was about $98 \%$ for every cycle within the same time.

To ascertain whether the catalyst was truly heterogeneous, or whether it acts as a reservoir for active soluble Pd, a filtration test was performed. In a typical experiment, Pd complex ( $0.1 \mathrm{~mol} \%)$, acrylamide ( $2 \mathrm{mmol})$, and $\mathrm{H}_{2} \mathrm{O}(6 \mathrm{ml})$ were taken in a round-bottomed flask and stirred at $35{ }^{\circ} \mathrm{C}$ for $30 \mathrm{~min}$. At this stage (52\% conversion), the catalyst was filtered off and the experiment continued with the filtrate for another $30 \mathrm{~min}$. There was no detectable increase in the product concentration. The conversion was $54 \%$, which was significantly lower than a 99\% conversion over $\mathrm{yPd} @ \mathrm{mSiO}_{2}-\mathrm{F}$ within the same time. These results can confirm the heterogeneous character of the catalytically active species. To verify the stability of the catalyst, the structure of the catalyst after fives uses was analyzed with $\mathrm{N}_{2}$ adsorption-desorption. The data show that the specific surface area is $382 \mathrm{~m}^{2} / \mathrm{g}$ and the pore volume is $0.23 \mathrm{~cm}^{3} / \mathrm{g}$, which is a little lower than those of the fresh catalyst. This demonstrates good stability of the developed catalyst.

\section{Conclusions}

In conclusion, a new $\mathrm{Pd}$ catalyst based on fluoro-functionalized yolk-shell-structured silica (yPd@mSiO $2-\mathrm{F}$ ) was prepared and applied in olefin hydrogenation. Characteri- zations show that the catalyst has a high specific area, and that its shell has uniformly distributed mesoporous channels. $\mathrm{yPd} @ \mathrm{mSiO}_{2}-\mathrm{F}$ show higher catalytic activity than $\mathrm{yPd} @ \mathrm{mSiO}_{2}$ for the hydrogenation of olefin. This is because the shell of yPd@mSiO 2 modified by fluoropropyl exhibits moderate hydrophobicity, which can drive the organic reactants into the intracavity of the yolk-shell. This promotes sufficient contact of the reactant and $\mathrm{Pd}$ nanoparticles, leading to high reaction rates. The activity of $\mathrm{yPd} @ \mathrm{mSiO}_{2}-\mathrm{F}$ did not significantly decrease after five reaction cycles, and the catalyst showed good stability. Our research preliminarily demonstrates that the unique structure and easy functionalization features make the yolk-shell-structured catalyst promising for more aqueous reactions.

\section{References}

[1] Wang J B, Qin R X, Xiong W, Jia Y, Liu D R, Feng J, Chen H. Chin J Catal (王金波, 秦瑞香, 熊伟, 贾云, 刘德蓉, 冯建, 陈华. 催化学 报), 2010, 31: 273

[2] Zhang Y, Wang M X, Wang D, Huang Z T. Progr Chem (张岩, 王梅 祥, 王东, 黄志镗. 化学进展), 1999, 11: 394

[3] Yang H Q, Jiao X, Li Sh R. Chem Commun, 2012, 48: 11217

[4] Ma Zh Ch, Yang H Q, Qin Y, Hao Y J, Li G. J Mol Catal A, 2010, 331 : 78

[5] Datta B, Pasha M A. Ultrasonics Sonochem, 2013, 20: 303

[6] Lu A, Cotanda P, Patterson J P, Longbottom D A, O’Reilly R K. Chem Commun, 2012, 48: 9699

[7] Xu X, Ji F Y, H L. J Civil Arch Envir Eng (徐璇，吉芳英，何莉. 土木建 筑与环境工程), 2011, 33: 129

[8] Kong F Z, Tian J H, Jin Z L. Petro Technol (孔凡志, 田建华, 金子林. 石油化工), 2002, 31: 387

[9] Huang L H, Chen C X, Liu Y L. Chin J Catal (黄浪欢, 陈彩选, 刘应 亮. 催化学报), 2006, 27: 1101

[10] Lin Y S, Wu S H, Tseng C T, Hung Y, Chang C, Mou C Y. Chem Commun, 2009: 3542

[11] Lee I, Albiter M A, Zhang Q, Ge J P, Yin Y D, Zaera F. Phys Chem Chem Phys, 2011, 13: 2449

[12] Guan Zh H, Hu J L, Gu Y L, Zhang H J, Li G X, Li T. Green Chem, 2012, 14: 1964

[13] Kim M, Park J C, Kim A, Park K H, Song H. Langmuir, 2012, 28: 


\title{
Graphical Abstract
}

Chin. J. Catal., 2013, 34: 1192-1200 doi: 10.1016/S1872-2067(12)60561-0

Pd nanoparticles confined in fluoro-functionlized yolk-shell-structured silica for olefin hydrogenation in water

LI Xiaofei, ZHANG Wenjuan, ZHANG Limin*, YANG Hengquan*

Shanxi Normal University; Shanxi University

The fluoro-functionlized yolk-shell-structured catalyst (yPd@mSiO $2-F)$ exhibited higher activity than the non-functionlized catalyst (yPd@ $\left.\mathrm{mSiO}_{2}\right)$ in the hydrogenation of olefins in water.

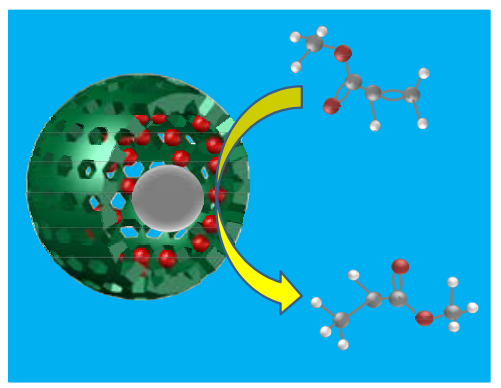

6441

[14] Fang X L, Liu Zh H, Hsieh M F, Chen M, Liu P X, Chen Ch, Zheng N F. ACS Nano, 2012, 6: 4434

[15] Wang Y L, Wang F Y K, Chen B D, Xu H, Shi D L. Chem Commun, 2011, 47: 10350

[16] Sun H, Shen X Sh, Yao L, Xing Sh X, Wang H, Feng Y H, Chen H Y.J Am Chem Soc, 2012, 134: 11243

[17] Kuo Ch H, Tang Y, Chou L Y, Sneed B T, Brodsky C N, Zhao Z P, Tsung C K. J Am Chem Soc, 2012, 134: 14345

[18] Wang F Y K, Tang Y L, Zhang B B, Chen B D, Wang Y L. J Colloid Interf Sci, 2012, 386: 129

[19] Wang P, Bai S Y, Li B, Yang Q H. Chin J Catal (王鹏, 白诗扬, 李博, 杨 启华. 催化学报), 2012, 33: 1689

[20] Li X B, Yang Y, Yang Q H.J Mater Chem A, 2013, 1: 1525

[21] Yang Y, Liu J, Li X B, Liu X, Yang Q H. Chem Mater, 2011, 23: 3676

[22] Chen H M, Liu R S, Lo M Y, Chang S C, Tsai L D, Peng Y M, Lee J F. J Phys Chem C, 2008, 112: 7522

[23] Tan L F, Chen D, Liu H Y, Tang F Q. Adv Mater, 2010, 22: 4885

[24] Zhu G R, Yang Q H, Jiang D M, Yang J, Zhang L, Li Y, Li C. J Chroma$\operatorname{tog} A, 2006,1103: 257$

[25] Shi Y F, Li B, Wang P, Dua R, Zhao D Y. Microporous Mesoporous
Mater, 2012, 155: 252.

[26] Wang P, Shi Q H, Shi Y F, Clark K K, Stucky G D, Keller A A. J Am Chem Soc, 2009, 131: 182

[27] Lin K F, Wang L F, Meng F Y, Sun Zh H, Yang Q, Cui Y M, Jiang D Zh, Xiao F Sh. J Catal, 2005, 235: 423

[28] Inumaru K, Ishihara T, Kamiya Y, Okuhara T, Yamanaka S. Angew Chem, Int Ed, 2007, 46: 7625

[29] Hamilton C E, Lomeda J R, Sun Zh Z, Tour j M, Barron A R. Nano Res, 2010, 3: 138

[30] Li Y Y, Kong N, Lin J J, Duan S P, Chen W, Tian S Y, Wang X B. Chin J Appl Chem (李远耀, 孔妮, 林晶晶, 段世鹏, 陈伟, 田思瑶, 王贤 保. 应用化学), 2012, 29: 251

[31] Stöber W, Fink A, Bohn E. J Colloid Interf Sci, 1968, 26: 62

[32] Chen Zh, Cui Zh M, Niu F, Jiang L, Song W G. Chem Commun, 2010, 46: 6524

[33] Lan Y, Zhang M Ch, Zhang W Q, Yang L. Chem Eur J, 2009, 15: 3670

[34] Zhang Y P, Xu Y, Liao S J, Shen Q. Chin J Catal (张一平, 徐筜, 廖世 健, 沈其. 催化学报), 1990, 11: 224

[35] Qiu K, Zhang Q, Jiang T, Ma L L, Wang T J, Zhang X H, Qiu M H. Chin J Catal (邱珂, 章青, 江婷, 马隆龙, 王铁军, 张兴华, 丘明煌. 催化 学报), 2011, 32: 612

\section{氟功能化蛋黄型氧化硅材料负载Pd纳米粒子用于水相烯烃加氢}

\author{
李晓菲 ${ }^{\mathrm{a}, \mathrm{b}}$, 张文娟 ${ }^{\mathrm{b}}$, 张丽敏 ${ }^{\mathrm{a},{ }^{*}}$, 杨恒权 ${ }^{\mathrm{b}, \#}$ \\ ${ }^{\mathrm{a}}$ 山西师范大学材料与化学学院, 山西临汾 041000 \\ b山西大学化学化工学院, 山西太原030006
}

摘要: 先将Pd纳米粒子负载于 $\mathrm{SiO}_{2}$ 球表面上, 再经包裹、刻蚀、硅烷化修饰, 得到氟丙基功能化 “蛋黄” 型结构催化剂. 并采用X 射线衍射、透射电镜、 $\mathrm{N}_{2}$ 吸附-脱附和热重等对催化剂进行了表征. 结果表明, 该催化剂在水相烯烃加氢反应中表现出较高的活 性, 明显高于未经氟丙基修饰的同类催化剂. 该催化剂通过离心便可实现回收, 多次循环使用后仍保持较高的活性.

关键词: 钯; 功能化; 烯烃; 水相; 加氢

收稿日期: 2012-12-24. 接受日期: 2013-03-05. 出版日期: 2013-06-20.

*通讯联系人. 电话: 13663578554; 电子信箱: zhangliminsxnu@gmail.com

\#通讯联系人. 电话: 13643472170; 电子信箱: hqyang@sxu.edu.cn

基金来源：国家自然科学基金(20903065, 21173137).

本文的英文电子版由Elsevier出版社在ScienceDirect上出版(http://www.sciencedirect.com/science/journal/18722067).

\section{1. 前言}

水是一种廉价、安全、无污染的绿色环保型溶剂, 近
年来以水为介质的催化反应引起了人们极大的兴趣 ${ }^{[1 ~ 6]}$. 然而, 大多数有机反应物与水互不相溶, 不利于反应物 与催化剂的充分接触, 导致水相催化反应速率普遍较低. 
为了提高反应速率, 通常情况下需加入表面活性剂或共 溶剂 ${ }^{[7,8]}$, 但给产品分离和纯化带来了困难. 因此, 研发 用于水相中有机反应的高效催化剂是一项富有挑战性 的课题.

“蛋黄” (yolk-shell)型介孔材料是近年来发现的一 种新型催化材料 ${ }^{[9 \sim 20]}$, 由于具有独特的结构, 而成为催化 领域的研究热点. 与介孔材料MCM-41和SBA-15相比, 该材料具有独特的中空结构, 密度小, 有利于催化剂悬 浮于水中. 而且中空结构和介孔壳层能使反应物分子很 快扩散到催化剂周围, 从而大幅度提高催化反应的速 率 ${ }^{[21,22]}$. 与传统核壳结构类材料相比, “蛋黄” 类材料的 外壳与内核间存在空腔结构, 可富集并容纳更多的反应 物分子, 有利于反应物和催化剂充分接触. 此外, 其介孔 壳能够对负载在壳内的金属纳米粒子起到保护作用, 同 时可提高催化剂的稳定性 ${ }^{[23]}$.

对于水相催化反应, 增加催化剂表面的疏水性有利 于提高催化剂的稳定性和活性. Yang课题组 ${ }^{[24]}$ 研究表 明, 经有机官能团修饰的介孔材料水热稳定性显著提高. Shi等 ${ }^{[25,26]}$ 发现, 疏水化修饰能提高材料对水中有机污染 物的吸附能力. Lin等 ${ }^{[27]}$ 也证明疏水性基团的引入可提 高水相催化反应速率. Inumaru等 ${ }^{[28]}$ 发现, 限阈在疏水性 微环境中的杂多酸表现出超高的催化活性. 由此可见, 疏水化修饰的催化剂能有效吸附反应物分子, 从而显著 提高反应速率. 但是, 催化剂疏水性过强不利于与反应 物接触, 使得催化剂活性降低. 氟丙基是一种中等疏水 性官能团, 用它修饰过的催化剂具有适中的疏水性 ${ }^{[29,30]}$, 能提高催化反应速率. 然而, 氟丙基功能化的 “黄蛋” 结构催化剂的制备及其在水相中有机反应的应用鲜见 报道.

本文先通过浸渍、还原将Pd负载于 $\mathrm{SiO}_{2}$ 上, 然后在 碱性条件下通过包裹、刻蚀得到 “蛋黄” 型氧化硅球 (yPd@ $\mathrm{mSiO}_{2}$ ), 最后将氟丙基嫁接到材料上, 制备得到功 能化 “蛋黄” 型催化剂( $\left.\mathrm{yPd} @ \mathrm{mSiO}_{2}-\mathrm{F}\right)$, 并采用X射线衍 射、透射电镜、 $\mathrm{N}_{2}$ 吸附-脱附和热重等技术对样品的结 构和组成等进行了表征, 通过水相加氢反应考察其催化 活性及循环使用性能.

\section{2. 实验部分}

\section{1. 催化剂的制备}

在 $500 \mathrm{ml}$ 的烧瓶中加入 $200 \mathrm{ml}$ 无水乙醇(AR, 天津 富宇试剂公司)、16 ml氨水(AR, 阿拉丁试剂公司)、12.2 $\mathrm{ml}$ 去离子水, 室温下搅拌 $30 \mathrm{~min}$ 后, 再加入 $12.4 \mathrm{ml}$ 正硅
酸乙酯(TEOS, AR, 阿拉丁试剂公司), 继续摚拌 $12 \mathrm{~h}$, 经 抽滤、去离子水反复洗涤至 $\mathrm{pH}$ 为中性后烘干, 即得到 $\mathrm{SiO}_{2}{ }^{[31]}$.

称取 $0.8 \mathrm{~g}$ 所制 $\mathrm{SiO}_{2}$ 材料于试管中, 加入 $10 \mathrm{ml}$ 乙酸钯 的甲苯溶液 (含乙酸钯 $8.4 \mathrm{mg}$ ), 室温下搅拌 $4 \mathrm{~h}$, 离心取走 上清液后, 加入 $16 \mathrm{ml}$ 的甲苯-乙醇混合液 $\left(V_{\text {甲莱: }} V_{\text {乙蟀 }}=\right.$ 20:1)和适量的 $\mathrm{NaBH}_{4}$ (阿拉丁试剂公司), 于室温还原 4 $h$, 然后离心分离得到固体, 用乙醇洗涤 4 次, 真空干燥, 即得到 $\mathrm{Pd} / \mathrm{SiO}_{2}$.

将0.6 g所制 $\mathrm{Pd} / \mathrm{SiO}_{2}$ 样品和 $120 \mathrm{ml}$ 去离子水加到 200 $\mathrm{ml}$ 圆底烧瓶中, 超声 $15 \mathrm{~min}$, 缓慢加到由 $0.9 \mathrm{~g}$ 十六烷基 三甲基溴化铵(CTAB, 阿拉丁试剂公司)、180 ml无水乙 醇、 $180 \mathrm{ml}$ 去离子水、 $3.3 \mathrm{ml}$ 氨水组成的混合液中, 于室 温摚拌 $30 \mathrm{~min}$ 后, 加入 $1.0575 \mathrm{~g}$ 的TEOS, 继续搅拌 $10 \mathrm{~h}$, 经抽滤、烘干后, 将其转到 $250 \mathrm{ml}$ 烧瓶中, 加入120 ml去 离子水超声至分散均匀, 再加入 $2.544 \mathrm{~g}$ 的 $\mathrm{Na}_{2} \mathrm{CO}_{3}(\mathrm{AR}$, 天津风船试剂公司), 在 $\mathrm{N}_{2}$ 保护下于 $50^{\circ} \mathrm{C}$ 搅拌 $12 \mathrm{~h}$ 对其 进行刻蚀. 最后, 抽干后经硝酸铵乙醇溶液萃取, 即得到 yPd@mSiO 2 .

称取 $0.5 \mathrm{~g}$ 的yPd@ $\mathrm{mSiO}_{2}$ 样品于试管中, 加入 $5 \mathrm{ml}$ 含 $0.1635 \mathrm{~g}(0.75 \mathrm{mmol})$ 三氟丙基三甲氧基硅烷(AR, 阿拉 丁试剂公司)的甲苯, 在 $\mathrm{N}_{2}$ 保护下于 $100{ }^{\circ} \mathrm{C}$ 回流 $4 \mathrm{~h}$, 然后 离心分离, 所得固体用甲苯和乙醇充分洗涤, 抽干, 即得 到yPd@mSiO $2-F$.

\section{2. 催化剂的表征}

采用日本JEOL JEM-2000EX型TEM进行形貌观测, 加速电压 $120 \mathrm{kV}$. 在液氮温度 $\left(-196{ }^{\circ} \mathrm{C}\right)$ 下, 以 $\mathrm{N}_{2}$ 为吸附 质在美国Micromeritics公司ASAP2020型物理吸附仪上 表征材料的比表面积. 采用 X射线衍射仪(D/max-2400 日本理学)进行物相和结构分析, $\mathrm{Cu} K_{a}$ 射线源, 管电压 40 $\mathrm{kV}$, 管电流 $100 \mathrm{~mA}$, 扫描速率 $5 \%$ min, 扫描角度分辨率 $0.02^{\circ}$. 采用热重分析仪(NETZSCH TG, 德国)对材料的 组成进行分析, $\mathrm{N}_{2}$ 气氛, 以 $25^{\circ} / \mathrm{min}$ 由室温升至 $900{ }^{\circ} \mathrm{C}$.

\section{3. 烯烃加氢反应}

烯烃加氢反应在配有水浴、热电偶以及磁力搅拌器 的三口圆底烧瓶中进行. 将 $6 \mathrm{ml}$ 的 $\mathrm{H}_{2} \mathrm{O}, 1 \mathrm{mmol}$ 烯烃反 应底物以及制备好的催化剂( $0.1 \mathrm{~mol} \%$ )加入反应器中. 通入氢气置换出反应器中的空气后, 将压力升至 0.15 MPa. 开启搅拌器(转速为 $500 \mathrm{r} / \mathrm{min}$ ), 加热至反应温度开 始反应. 反应结束后, 离心分离出催化剂. 反应产物采 用美国Agilent 7890A型气相色谱分析仪分析, FID检测 器. 


\section{3. 结果与讨论}

\section{1. 催化剂制备过程与表征结果}

$\mathrm{yPd} @ \mathrm{mSiO}_{2}$ 的制备过程分为四步 (见图1). 为了将 Pd 纳米粒子固载于 “蛋黄” 材料内部, 先通过浸渍、还 原将 $\mathrm{Pd}$ 纳米粒子负载于 $\mathrm{SiO}_{2}$ 球上, 在 $\mathrm{CTAB}$ 存在下在其 表面上生长一层 $\mathrm{SiO}_{2}$ 壳, 然后在碱性条件下用 $\mathrm{Na}_{2} \mathrm{CO}_{3}$ 对 $\mathrm{SiO}_{2}$ 内核进行刻蚀, 最后通过溶剂萃取去除模板剂即得 到 “蛋黄” 型结构催化剂. 与采用高温焙烧去除碳球得 到中空结构的方法 ${ }^{[2]}$ 相比, 该方法制备条件温和, 避免 了因高温焙烧引起的结构塌陷及催化活性组分失活.

图 2 为每一步合成样品的 $\mathrm{N}_{2}$ 吸附-脱附等温曲线, 相 应织构参数列于表1. 可以看出, $\mathrm{SiO}_{2}$ 球的比表面积仅为 $18 \mathrm{~m}^{2} / \mathrm{g}$, 孔体积为 $0.06 \mathrm{~cm}^{3} / \mathrm{g}$. $\mathrm{Pd} / \mathrm{SiO}_{2}$ 经 $\mathrm{SiO}_{2}$ 包裏得到 $\mathrm{Pd} / \mathrm{SiO}_{2} @ \mathrm{mSiO}_{2}$, 其吸附曲线为 IV 型, 在相对压力 0.1 0.3间出现毛细管凝聚现象; 其吸附量明显增大, 比 表面积和孔体积分别增至 $408 \mathrm{~m} \mathrm{~m}^{2} / \mathrm{g}$ 和 $0.23 \mathrm{~cm}^{3} / \mathrm{g}$, 这是由 于 $\mathrm{CTAB}$ 存在下, $\mathrm{Pd} / \mathrm{SiO}_{2}$ 表面形成了 $\mathrm{SiO}_{2}$ 孔道结构. 经 刻蚀得到 $\mathrm{yPd} @ \mathrm{mSiO}_{2}$ 的吸附的吸附等温线也表现为典 型的IV型, 在相对压力0.3 0.5间出现了毛细管凝聚现 象, 表明具有介孔结构; 且 $\mathrm{yPd} @ \mathrm{mSiO}_{2}$ 在相对压力 0.5 1.0范围内的吸附分支和脱附分支没有重合, 出现明 显的 $\mathrm{H} 4$ 型滞后环, 证明该材料具有中空结构。与 $\mathrm{Pd} / \mathrm{SiO}_{2} @ \mathrm{mSiO}_{2}$ 相比, $\mathrm{yPd} @ \mathrm{mSiO}_{2}$ 的比表面积和孔体积 显著增加, 分别高达 $841 \mathrm{~m}^{2} / \mathrm{g}$ 和 $1.01 \mathrm{~cm}^{3} / \mathrm{g}$. 这主要是由 于yPd@ $\mathrm{mSiO}_{2}$ 的 $\mathrm{SiO}_{2}$ 内核被刻蚀掉, 模板剂也得以充分 的去除. 经氟丙基修饰后, 所得 $\mathrm{yPd} @ \mathrm{mSiO}_{2}-\mathrm{F}$ 样品吸附 曲线类型未发生改变, 但其比表面积、孔体积和孔径都 明显减小, 表明氟丙基成功引入到 $\mathrm{yPd} @ \mathrm{mSiO}_{2}$ 材料上.

图3 是 $\mathrm{SiO}_{2}, \mathrm{Pd} / \mathrm{SiO}_{2}$ 和 $\mathrm{yPd} @ \mathrm{mSiO}_{2}$ 的TEM照片. 由 图可见, 所合成的 $\mathrm{SiO}_{2}$ 由大小均匀、高分散的小球组成, 其直径在 $200 \mathrm{~nm}$ 左右; 将Pd纳米粒子负载到 $\mathrm{SiO}_{2}$ 表面上 得到的 $\mathrm{Pd} / \mathrm{SiO}_{2}$ 样品中 $\mathrm{Pd}$ 粒子的大小基本均匀, 尺寸为 $4 \sim 10 \mathrm{~nm}$; 经包裹、刻蚀得到的 $\mathrm{yPd} @ \mathrm{mSiO}_{2}$ 材料由许多 小球颗粒组成, 其大小相对均匀, 尺寸在 $500 \mathrm{~nm}$ 左右. 与 $\mathrm{SiO}_{2}$ 球相比, $\mathrm{yPd} @ \mathrm{mSiO}_{2}$ 微球的尺寸明显增大; 大多数 小球颗粒由内核与外壳组成, 且两者之间存在空腔, 与 图2一致. 图4为yPd@mSiO 2 和 $y \mathrm{Pd} @ \mathrm{mSiO}_{2}-\mathrm{F}$ 的XRD谱. 由图可见, $\mathrm{yPd} @ \mathrm{mSiO}_{2}$ 在 $2 \theta \approx 2.3^{\circ}$ 处出现了较强的衍射 峰, 进一步证明所合成的 “蛋黄” 型氧化硅球外壳具有 介孔结构. 氟丙基修饰后, 材料在 $2 \theta \approx 2.3^{\circ}$ 处依然有衍 射峰, 且峰强度基本保持不变, 说明氟丙基的引入并未 破坏材料的有序结构.
图5是yPd@mSiO 2 和 $\mathrm{yPd} @ \mathrm{mSiO}_{2}-\mathrm{F}$ 的 $\mathrm{TG}$ 曲线. 由图 可见, 在室温 $~ 900{ }^{\circ} \mathrm{C}, \mathrm{Pd} @ \mathrm{mSiO}_{2}$ 存在三个失重峰: 低于 $200{ }^{\circ} \mathrm{C}$ 时, 样品失重 $3.48 \%$, 可归属于材料表面物理吸附 的水; $200 \sim 320^{\circ} \mathrm{C}$ 失重 $4.4 \%$, 这是由少量表面活性剂的 分解所致; 在320 650 ${ }^{\circ} \mathrm{C}$ 样品失重 $3.54 \%$, 主要是由硅羟 基高温缩合脱水造成. $\mathrm{Pd} @ \mathrm{mSiO}_{2}$ - $\mathrm{F}$ 样品失重也分为三 个阶段: 低于 $200{ }^{\circ} \mathrm{C}$ 失重 $1.17 \%$, 明显低于 $\mathrm{Pd} @ \mathrm{mSiO}_{2}$, 这 是由于氟丙基的引入使材料表面的疏水性增强, 吸附水 的量减少; 在 $200 \sim 320^{\circ} \mathrm{C}$ 间失重3.16\%, 这也是因少量表 面活性剂的分解所致; 在320 650 ${ }^{\circ} \mathrm{C}$ 失重高达 $15.31 \%$, 主要是由共价键连接的氟丙基的分解和少量硅羟基在 高温条件下缩合脱水造成. 经比较, 可估算出氟丙基的 负载量为 $1.2 \mathrm{mmol} / \mathrm{g}$, 与元素分析结果基本吻合.

\section{2. 催化剂的活性}

烯烃加氢反应在精细化学品合成中有着广泛的应 用, 许多学者正在寻求水相反应的高效催化剂, 并取得 了可喜的进展 ${ }^{[33-35]}$. 因此, 本文选择水相加氢反应来评 价新型 “蛋黄” 型核壳结构催化剂的性能. 将催化剂 $\mathrm{yPd} @ \mathrm{mSiO}_{2}-\mathrm{F}$ 和 $\mathrm{yPd} @ \mathrm{mSiO}_{2}$ 用于丙烯酸甲酯加氢反应 中, 通过跟踪 $\mathrm{H}_{2}$ 压降来比较反应速率, 结果示于图6. 可 以看出, 相同的反应条件下, $\mathrm{yPd} @ \mathrm{mSiO}_{2}-\mathrm{F}$ 的耗氢速率 明显大于yPd@ $\mathrm{mSiO}_{2}$, 表明前者催化活性更高. 如图7 所示, 两种催化剂上甲基丙烯酸乙酯的压降均随时间延 长而下降, 但 $\mathrm{yPd} @ \mathrm{mSiO}_{2}-\mathrm{F}$ 的压降速度明显更快, 与图6 结果一致. 由此可见, $\mathrm{yPd} @ \mathrm{mSiO}_{2}-\mathrm{F}$ 具有更高的催化活 性.

为了进一步考察催化剂的性能, 将 $\mathrm{yPd} @ \mathrm{mSiO}_{2}$ 和 $\mathrm{yPd} @ \mathrm{mSiO}_{2}-\mathrm{F}$ 用于其它烯烃加氢反应中, 结果示于表 2. 可以看出, 以苯乙烯为底物, 反应 $45 \mathrm{~min}, \mathrm{yPd} @ \mathrm{mSiO}_{2}$ 和 $\mathrm{yPd} @ \mathrm{mSiO}_{2}-\mathrm{F}$ 上苯乙烯转化率分别是 $45 \%$ 和 $88 \%$. 对于 脂肪类烯烃, 如丙烯酸丁酯、丙烯酸甲酯、甲基丙烯酸 丁酯等, 在相同反应条件下, $\mathrm{yPd} @ \mathrm{mSiO}_{2}-\mathrm{F}$ 上底物的转 化率明显高于 $\mathrm{yPd} @ \mathrm{mSiO}_{2}$. 以丙烯酰胺为底物, 反应 60 min时, $\mathrm{yPd} @ \mathrm{mSiO}_{2}$ 对应的转化率是 $49 \%, \mathrm{yPd} @ \mathrm{mSiO}_{2}-\mathrm{F}$ 对应的转化率是 $99 \%$, 后者是前者的 2 倍. 综上可见, 在 水相烯烃加氢反应中, $\mathrm{yPd} @ \mathrm{mSiO}_{2}-\mathrm{F}$ 的催化活性明显高 于 $\mathrm{yPd} @ \mathrm{mSiO}_{2}$. 这是由于 $\mathrm{yPd} @ \mathrm{mSiO}_{2}$ 的壳层经氟丙基 修饰后具有中等程度的疏水性, 有利于将水相中低浓度 的有机反应物富集到 “蛋黄” 型材料的腔内, 使反应物 和Pd金属粒子充分接触, 进而提高催化反应速率.

\section{3. 催化剂的循环使用性能}

在纯水介质中, 以丙烯酸丁酯加氢反应来评价 
$\mathrm{yPd} @ \mathrm{mSiO}_{2}-\mathrm{F}$ 催化剂的循环使用性能, 结果列于表3. 可 以看出, 第一次使用时反应 $90 \mathrm{~min}$ 底物转化率为 $99 \%$. 反应结束后, 通过离心、洗涤回收催化剂, 真空干燥后直 接加入底物用于第二次反应, 反应相同时间底物转化率 仍可达 $99 \%$. 使用至第五次底物转化率仍可达 $99 \%$. 由 此可见, $\mathrm{yPd} @ \mathrm{mSiO}_{2}-\mathrm{F}$ 具有良好的循环使用性能, 且该 催化剂易回收.

为了验证在反应过程中yPd@ $\mathrm{mSiO}_{2}-\mathrm{F}$ 催化剂上的 活性组分Pd纳米粒子是否流失, 我们对滤液进行了实验. 按表2实验4的条件, 反应30 min后停止, 经高速离心后得 到滤液, 测得丙烯酰胺的转化率达 $52 \%$; 然后, 相同条件 下继续反应 $30 \mathrm{~min}$, 底物转化率没有明显的增加(54\%), 远低于相同时间内在催化剂存在下 $99 \%$ 的转化率(见表 2 , 实验 4$)$, 说明在反应过程中对转化率的贡献来源于催 化剂上的活性组分, 而不是滤液中流失的Pd纳米粒子. 这表明“蛋黄”型结构能有效阻止Pd纳米粒子的流失. 为 了进一步验证催化剂的稳定性, 我们测得循环使用5次
后的yPd@mSiO $2-\mathrm{F}$ 样品的比表面积和孔体积分别为382 $\mathrm{m}^{2} / \mathrm{g}$ 和 $0.45 \mathrm{~cm}^{3} / \mathrm{g}$; 与新鲜的催化剂相比稍有所降低, 证 明该催化剂具有良好的水热稳定性.

\section{4. 结论}

通过包裹、刻蚀、硅烷化修饰成功地将Pd负载于“蛋 黄” 型氧化硅材料内, 得到了氟丙基功能化的 “蛋黄” 型结构催化剂. 结果显示, 该催化剂比表面积较大, 壳层 外具有均匀分布的介孔孔道. 在水相烯烃加氢反应中 $\mathrm{yPd} @ \mathrm{mSiO}_{2}-\mathrm{F}$ 的活性高于 $\mathrm{yPd} @ \mathrm{mSiO}_{2}$. 这可能是由于 $\mathrm{yPd} @ \mathrm{mSiO}_{2}$ 的壳层经氟丙基修饰后具有中等程度的疏 水性, 有利于将水相中低浓度的有机反应物富集到 “蛋 黄” 型材料的腔内, 使反应物和 $\mathrm{Pd}$ 金属粒子充分接触, 进 而提高催化反应速率. $\mathrm{yPd} @ \mathrm{mSiO}_{2}-\mathrm{F}$ 循环使用5次后活 性没有降低, 表明其具有良好的稳定性. 独特的结构和 易功能化的特点使 “蛋黄” 型结构催化剂在水相反应中 具有良好的应用前景. 